\title{
Analysis of Influence of Perception of School Leadership and Work Motivation on the Teacher Performance (Case Study in Private School Depok)
}

\author{
Heru Sriyono \\ Fakultas Pendidikan dan Ilmu Pengetahuan Sosial, Universitas Indraprasta PGRI-Jakarta
}

\begin{abstract}
This study analyzes the effect of teacher perceptions on school leadership, work motivation on teacher performance on the performance of Depok Private Junior High School teachers. The method used is a survey method with an associative approach to determine the relationship of related variables. The target population of the study is private junior high school teachers in Depok City with a total of 510 teachers with a sample of 60 teachers. This study found that the performance of private junior high school teachers in Depok was influenced by teachers' perceptions of school principal leadership along with work motivation, because the value of Fcount = $12.856>$ Ftable $=3.19$
\end{abstract}

Keywords: Teacher Perceptions of Principal Leadership, Work Motivation, Teacher Performance.

DOI: $10.7176 / \mathrm{JEP} / 11-3-11$

Publication date: January $31^{\text {st }} 2020$

\section{Introduction}

In the context of the implementation of school-based management, a the teacher's performance is influenced by several factors, namely the principal's leadership style, school organization's atmosphere, the atmosphere of the school environment and the teacher's work motivation. The principal's ability to realize if effective leadership will improve teacher performance. Moreover if the teachers who have high motivation in carrying out their main tasks will also improve their performance. Principals with good leadership and high motivation will further accelerate the improvement of teacher performance if a teacher has adequate capabilities, namely the educational background of the teacher.

In line with the implementation of the decentralization of education with school autonomy as a feature, the implementation of teaching and learning activities affects teacher performance. The implementation of teaching and learning is in accordance to paradigm so that it will ultimately improve teacher performance. Improving the quality of national education as an integral part in improving the quality of Indonesian people as a whole.

In the process of improving the quality of human resources, education plays a very important role. Then the process of improving the quality of human resources is an integral part of the process of improving the quality of education. A tangible form of improving the quality of education in Indonesia, there is collaboration between the government and the private sector that is continuously undertaking: improving curriculum and learning systems, facilities and education, procuring and developing teaching materials, as well as training for teachers and education staff.

Education is part of efforts to increase knowledge in the formation of values, attitudes, and human behavior, one interesting government program is the completion of the thirteen curriculum (kurtilas). This is a determined effort of the Indonesian people to improve the quality of human resources of the Indonesian people. Indonesian citizens have the right to get a good education, so education must be able to provide a maximum educational service so that the quality of graduates can be improved. One factor that measures the success of education is to improve teacher performance, because teachers are the spearhead of the implementation of educational policies, which are assessed from the planning process to the assessment.

In addition to the principal's leadership that supports teacher performance, work motivation needs to be considered. Motivation is a basic impulse that moves a person to behave. This impulse is in someone who moves to do something that is in accordance with the motivation in him. Therefore, a person's actions based on a certain motivation contain elements in accordance with the underlying motivation.

Teachers are educational staff making the dominant factor determining success in ignoring educational goals, because teachers who deal directly with citizens learn in the learning process to produce competent graduates as targeted. Teachers as planners, implementers and determinants in achieving educational goals, require support from the principal as a figure and high work motivation through a conducive school atmosphere with good relations among teachers, administrative staff and students.

\section{THEORY REVIEW}

Perception

The perception of the nature of the activities of sensing, integrating and providing an assessment of physical and 
social objects contained in their environment. The signals coming from the environment are processed together with what has been learned before, in the form of attitudes, values and memories as well as expectations. Perception will form a stable tendency to behave in certain ways in certain situations. For this reason, perception is the process of a person's activity to give an impression, judgment, opinion and feel and interpret something based on information obtained from the perceived source. Through perception one can recognize all the events that exist. Through our perception we can interact with the environment around us,

According to Malayu SP Hasibuan (2007: 327) "Leadership is a way for someone to influence the behavior of subordinates to be able to work together in achieving organizational goals". Hadari Nawawi (2003: 38) states "leadership as the ability to make decisions to influence others. In this sense there are two main dimensions, namely:

a. The first dimension relates to the ability to direct every leader's activities, in carrying out the leader's functions. b. The second dimension relates to control in leadership, which is indicated by the support for the involvement of subordinates.

A leader is someone with the ability to lead. People who have the ability to relate to humans, are able to place or have influence. At this frequency includes the ability to delegate a person with elements of command, training, direction or supervision. Alle in Kartono (2002: 23) leaders are guides, guides, determinants and commanders.

Principal's leadership

Mulyasa (2003: 107) Principal leadership is an ability in improving the performance of teachers, both individuals or groups. A good leader can motivate and direct individuals in group collaboration so they can achieve school goals. Thus the Principal's Leadership is the Principal's ability to carry out his duties and functions in realizing the vision, mission and goals of the school. Irawan (2003) indicators of Principal Leadership ability as follows: 1). Educator, 2). Manager, 3) administrator, 4) supervisor, 5). Leader, 6). Innovator and 7). Motivator.

Teacher's perception of the Principal's leadership

Based on the description above, the teacher's perception of the principal's leadership is someone who leads the place where the teacher teaches in carrying out their duties and functions in realizing the vision, mission and goals of the school.

The assessment is based on the principal's leadership indicators that are in accordance with the duties and functions of the principal, namely his ability as: 1). Educator, 2). Manager 3). Administrator, 4). Supervisor, 5). Leader, 6). Innovator and 7). Motivator.

Teacher

Teachers who are very important an idiom that symbolizes the truly noble teaching profession. This is very appropriate to be attached to the profession of a teacher. Considering the teacher is actually an educator who provides examples and educational services for their students. A student must follow all the commands and examples given by his teacher, because students see that the teacher is a figure that deserves to be emulated, both through attitudes, words and deeds.

Work motivation

Gorton in Irawan (2003: 42), work motivation is an encouragement to do work. This motivation is closely related to the work relationship or behavior of a teacher. The process of work motivation begins with a sense of lack of need, which drives to get so that a search process arises, then people have a certain set of actions.

From the description above, what is meant by motivation is the encouragement of someone in achieving the best work performance marked by indicators of motivation: 1) behavior, 2) effort, 3) perseverance, 4) attention, 5) discipline, 6) crafts.

\section{RESEARCH METHODS}

The method used in this study survey method with a quantitative correlational approach. According to Singarimbun and Effendi (1999: 3) "survey method is a study that takes samples from the population and uses a data collection tool questionnaire. According to Kerlinger (2000: 661) "survey research is making accurate estimates of the characteristics of the whole population. According to Singarimbun and Effendi (1999: 4) that "the type of survey research consists of several steps including: (1) exploratory (explorative) (2) descriptive (3) explanation (4) evaluation (5) prediction or forecasting (6) research operational (7) development of social indicators "

Data analysis uses the method of multiple regression analysis, to see the effect between two independent variables with one dependent variable. According to Sudjana (2005: 67) "in the regression analysis the main thing analyzed is the regression coefficient which is the number that shows the influence between variables that have a causal relationship and cancel each other out of change". In this study there are three variables, namely: teacher performance $(\mathrm{Y})$ and two independent variables, namely the teacher's perception of the principal's leadership (X1) and work motivation (X2). The data used in this study were taken using a questionnaire.

\section{RESULTS AND DISCUSSION}

Teacher Performance (Variable Y) 
To describe data about teacher performance (Variable Y) of Depok City Junior High School, researchers present the table below based on the results of data processing with SPSS.

Tabel I ; Teacher Performance (Variable Y)

\begin{tabular}{|c|c|c|}
\hline \multicolumn{3}{|c|}{ Statistics } \\
\hline \multicolumn{3}{|c|}{ Teacher performance } \\
\hline \multirow{2}{*}{$\mathrm{N}$} & Valid & 60 \\
\hline & Missing & 0 \\
\hline Mean & & 114.55 \\
\hline Median & & 115.00 \\
\hline Mode & & 115 \\
\hline Std. Deviation & & 9.546 \\
\hline Minimum & & 95 \\
\hline Maximum & & 130 \\
\hline
\end{tabular}

As can be seen on table I above, it is an illustration of the level of performance of 60 teachers as research samples, known to the level of performance of teachers who have the lowest score of 95, the highest value of 130 , an average value of 114.55, a median of 115.00, mode 115, and std. Deviation 9,546. This shows that the performance of Depok City Junior High School teachers is in the medium category, this condition is shown by Mean is almost the same as the median (114.55 approaching 115).

Teacher Perception of Principal Leadership (X1)

To describe data about Teacher Perceptions of School Principal Leadership (Variable X1) of Depok City Junior High School, researchers present the table below based on the results of data processing with SPSS.

Tabel II ; Data of Teacher Preception to leadership (Variable $\mathrm{X}_{1}$ )

\begin{tabular}{|c|c|c|}
\hline \multicolumn{3}{|c|}{ Statistics } \\
\hline$N$ & Valid & 60 \\
\hline $\mathbb{N}$ & Missing & 0 \\
\hline Mean & & 115.67 \\
\hline Median & & 113.00 \\
\hline Mode & & 113 \\
\hline Std. Deviation & & 8.560 \\
\hline Minimum & & 98 \\
\hline Maximum & & 133 \\
\hline
\end{tabular}

Based on table II above, it can be seen the teacher perception data on the leadership of the Principal obtained an answer questionnaire score of 60 teachers as research samples, has a minimum value of 98 , a maximum value of 133, a mean value of 115.67 , a median value of 113.00 , a mode value of 113 , and a value standard deviation 8,560. This states that the influence of teacher perception on the leadership of the Principal of the Depok City Junior High School is good. This condition is indicated by the mean value above the median value or 115.67> 113. Work motivation (X2)

To describe the data about work motivation of Depok City Junior High School teachers, researchers copy the table below.

Tabel III ; Teacher motivation (Variable $\mathrm{X}_{2}$ )

\begin{tabular}{|l|l|r|}
\hline \multicolumn{2}{|c|}{ Statistics } \\
\hline \multirow{2}{*}{$\mathrm{N}$} & Valid & 60 \\
\cline { 2 - 3 } & Missing & 0 \\
\hline Mean & 114.83 \\
\hline Median & 113.00 \\
\hline Mode & 113 \\
\hline Std. Deviation & 8.971 \\
\hline Minimum & 98 \\
\hline Maximum & 133 \\
\hline
\end{tabular}

Based on table III above which is processed from the questionnaire answers to 60 teachers as research samples, it is known that the level of work motivation with the lowest value is 98 , the highest value is 133 , the average value is 114.83 , the median is 113.00 , the mode is 113 , and std. Deviation 8,971 .

From the calculation above, it is said that the work motivation of SMPS teachers in Depok is good. This is proved by the Mean value better than the Median value (114.83> 113.00

Data Normality Test. 
Tabel IV ; Normality

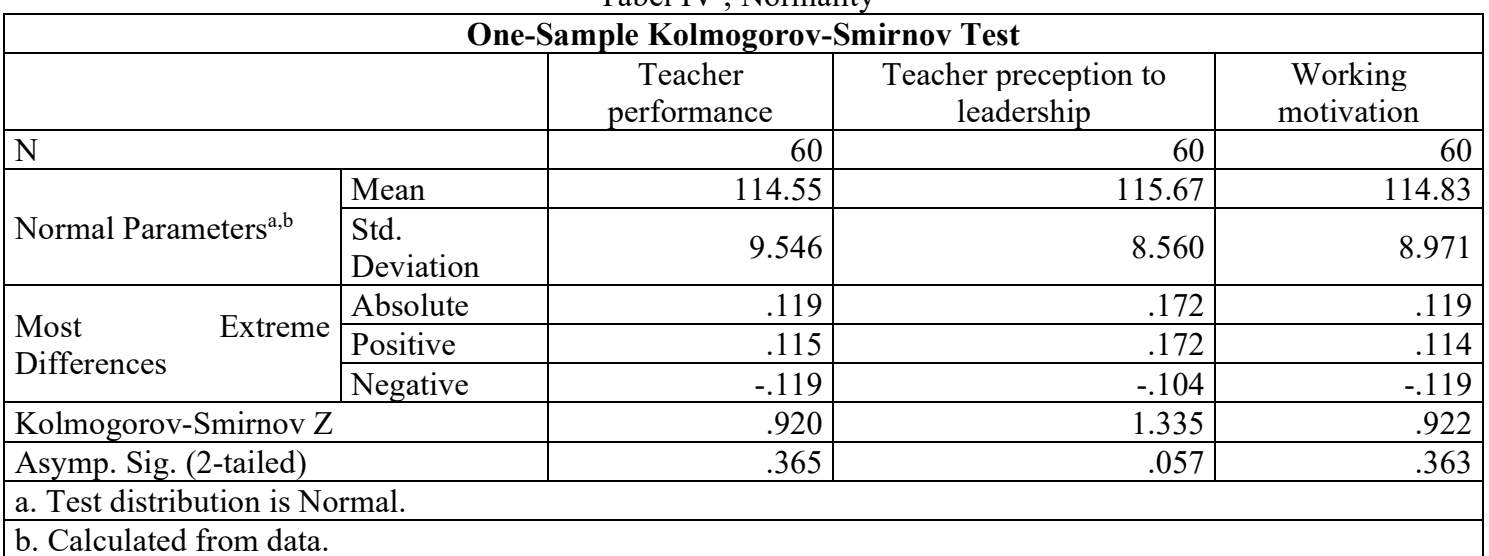

From Table IV above it is known that the A value. Sig $>0.05$, this proves that all data are normally distributed and meet the requirements used in regression analysis.

Data Multicollinearity Test

The test is to see if there is no correlation between independent variables perfectly. To use a regression model, it needs to do a multicollinearity test with the aim to find out whether there is a perfect correlation between independent variables. There is a correlation between independent variables perfectly (multicollinearity) as evidenced by: tolerance $<0.1$ or inflation factor variant (VIF). $>10$.

Tabel V; Multi colinearity data test

\begin{tabular}{|l|l|r|r|}
\hline \multicolumn{3}{|c|}{ Coefficients $^{\mathbf{2}}$ Model } \\
\cline { 3 - 4 } \multicolumn{2}{|l|}{} & \multicolumn{2}{|c|}{ Collinearity Statistics } \\
\hline \multirow{3}{*}{1} & (Constant) & Tolerance & \multicolumn{1}{c|}{ VIF } \\
\cline { 2 - 4 } & Teacher perception & .814 & 1.229 \\
\cline { 2 - 4 } & Working motivation & .814 & 1.229 \\
\hline & & & \\
\hline
\end{tabular}

Multicollinearity test results In table $\mathrm{V}$ above it is known that the teacher's perception of the leadership of the principal there is no influence of multicollinearity on work motivation, this is indicated by Tolerance $0.814>0.1$ or variant inflation factor (VIF) $1.222<10$, so this proof can be the reason for using the multiple regression analysis method in this study.

Data Heteroscedasticity Test

The Regression Standardized Pradicted Value of the cross section data by carrying out a data heteroscedasticity test. Heteroscedasticity test data is used to see the observed error values do not have a constant difference.

For heteroscedasticity test data can be carried out by making a scatterplot between standardized residuals (ZRESID) and standardized predicted values. To test the heteroscedasticity of the data to be used in this study, the researchers present the scatterplot image below. 


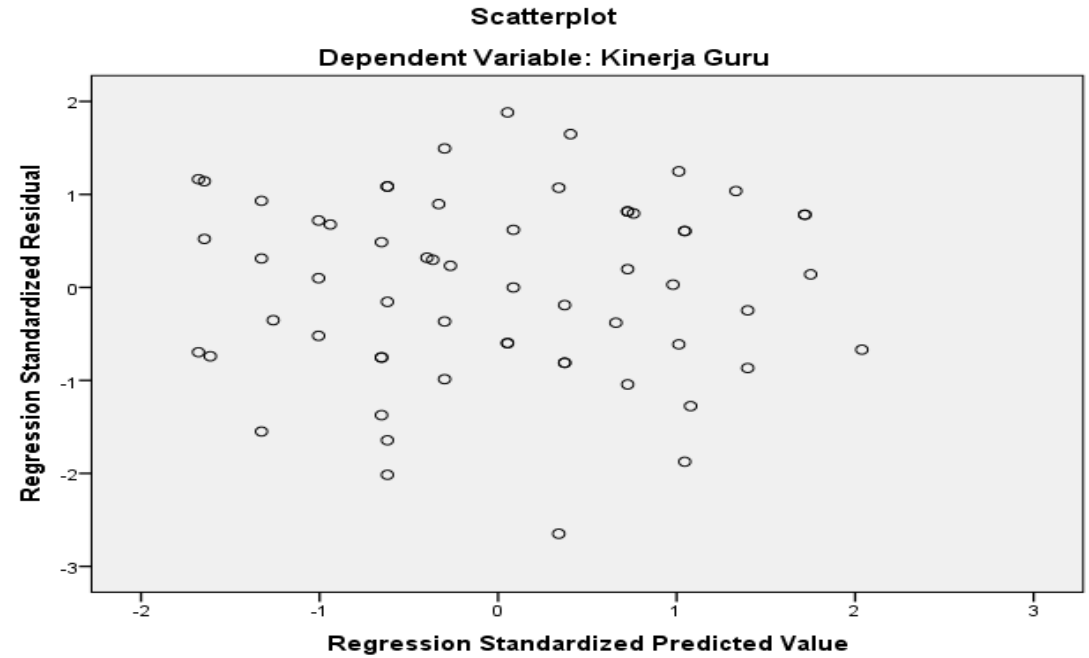

Based on the the picture of above, it is seen that there is no formation of certain patterns of data distribution above or below the zero point, this states there is no heteroscedasticity in the data used in this study to predict that teacher performance is based on the influence of teacher perceptions of school leadership and motivation work.

Data Error Normality Test

Data Error Normality Test is used to determine whether the data used in this study are normally distributed, as one of the good data requirements in using multiple regression analysis methods.

\begin{tabular}{|l|l|r|}
\hline \multicolumn{2}{|c|}{ One-Sample Kolmogorov-Smirnov Test } \\
\hline $\mathrm{N}$ & Mean & Unstandardized Residual \\
\hline \multirow{2}{*}{ Normal Parameters ${ }^{\mathrm{a}, \mathrm{b}}$} & Std. Deviation & 60 \\
\cline { 2 - 3 } & Absolute & $.0 \mathrm{E}-7$ \\
\cline { 2 - 3 } Most Extreme Differences & Positive & .068 \\
\cline { 2 - 3 } & Negative & -.098 \\
\hline Kolmogorov-Smirnov Z & .758 \\
\hline Asymp. Sig. (2-tailed) & .613 \\
\hline a. Test distribution is Normal. \\
\hline \multicolumn{2}{|l|}{ b. Calculated from data. } \\
\hline
\end{tabular}

From table VI above, it is known that $\mathrm{Z}=0.758$ or Sig. $=0.613>0.05$, this proves that the data used in this study are normally distributed, so the use of multiple regression analysis methods in this study meets the requirements $/$.

Data Linearity Test Descriptions

Linearity Regression X1 over Y

Linearity test between the effect of teacher perceptions on the leadership of school principals with teacher performance, explained using table VII below.

Tabel VII. Linearity test $\mathrm{X}_{1}$ to $\mathrm{Y}$

\begin{tabular}{|c|c|c|c|c|c|c|c|}
\hline \multicolumn{8}{|c|}{ ANOVA Table } \\
\hline & & & $\begin{array}{l}\text { Sum of } \\
\text { Squares }\end{array}$ & $\mathrm{df}$ & $\begin{array}{l}\text { Mean } \\
\text { Square }\end{array}$ & $\mathrm{F}$ & Sig. \\
\hline \multirow{5}{*}{$\begin{array}{l}\text { Teacher performance, teacher } \\
\text { preception to principa } \\
\text { leadership }\end{array}$} & \multirow{3}{*}{$\begin{array}{l}\text { Between } \\
\text { Groups }\end{array}$} & (Combined) & 1277.602 & 7 & 182.515 & 2.315 & .039 \\
\hline & & Linearity & 1126.642 & 1 & 1126.642 & 14.292 & .000 \\
\hline & & \begin{tabular}{|ll} 
Deviation from \\
Linearity
\end{tabular} & 150.960 & 6 & 25.160 & .319 & .924 \\
\hline & \multicolumn{2}{|c|}{ Within Groups } & 4099.248 & 52 & 78.832 & & \\
\hline & \multicolumn{2}{|l|}{ Total } & 5376.850 & 59 & & & \\
\hline
\end{tabular}

Based on table VII, it is known that the results of $\mathrm{Fo}=0.319$ and Sig. $=0.924>0.05$, this proves the existence of a linear relationship between the teacher's perception of the Principal's leadership and the teacher's performance. Linearity Regression X2 over Y

Linearity testing of work motivation with teacher performance is carried out using data table IX below.

Tabel IX ; Linearity test $\mathrm{X}_{2}$ to $\mathrm{Y}$ 


\begin{tabular}{|c|c|c|c|c|c|c|c|}
\hline \multicolumn{8}{|c|}{ ANOVA Table } \\
\hline & & & $\begin{array}{l}\text { Sum of } \\
\text { Squares }\end{array}$ & $\mathrm{df}$ & $\begin{array}{l}\text { Mean } \\
\text { Square }\end{array}$ & $\mathrm{F}$ & Sig. \\
\hline \multirow{5}{*}{$\begin{array}{l}\text { Teacher } \\
\text { performance to } \\
\text { working } \\
\text { motivation }\end{array}$} & \multirow{3}{*}{$\begin{array}{l}\text { Between } \\
\text { Groups }\end{array}$} & (Combined) & 1520.279 & 7 & 217.183 & 2.928 & .012 \\
\hline & & Linearity & 1263.612 & 1 & 1263.612 & 17.038 & .000 \\
\hline & & $\begin{array}{l}\text { Deviation from } \\
\text { Linearity }\end{array}$ & 256.667 & 6 & 42.778 & .577 & .747 \\
\hline & \multicolumn{2}{|c|}{ Within Groups } & 3856.571 & 52 & 74.165 & & \\
\hline & \multicolumn{2}{|c|}{ Total } & 5376.850 & 59 & & & \\
\hline
\end{tabular}

Based on table IX above, the result is Fo $=0.577$ and Sig. $=0.747>0.05$, which proves the existence of a linear relationship between work motivation variables and teacher performance.

Teacher Performance Together Influenced Teacher Perception of Principal Leadership and Work Motivation Testing the linearity of teachers' perceptions of Principal's leadership, work motivation and teacher performance, is carried out using data table IX below

Tabel X. Double regretion $\mathrm{X}_{1}$ and $\mathrm{X}_{2}$ to $\mathrm{Y}$

\begin{tabular}{|c|c|c|c|c|c|c|}
\hline \multicolumn{7}{|c|}{ Coefficients $^{\mathbf{a}}$} \\
\hline \multirow{2}{*}{\multicolumn{2}{|c|}{ Model }} & \multicolumn{2}{|c|}{ Unstandardized Coefficients } & Standardized Coefficients & \multirow[t]{2}{*}{$\mathrm{t}$} & \multirow[t]{2}{*}{ Sig. } \\
\hline & & $\mathrm{B}$ & Std. Error & Beta & & \\
\hline \multirow{3}{*}{1} & (Constant) & 32.038 & 16.369 & & 1.957 & .055 \\
\hline & Teacher preception & .341 & .136 & .305 & 2.505 & .015 \\
\hline & Motivation & .376 & .130 & .353 & 2.895 & .005 \\
\hline
\end{tabular}

Based on table IX above, the multiple regression equation yielded $\mathrm{Y}^{\wedge}=32.038+0.341 \mathrm{X} 1+0.376 \mathrm{X} 2$, meaning that a change in one teacher's perception score of the Principal's leadership results in a change in the teacher's performance score of 0.341 and a change in one work motivation score resulting in a change in the teacher's performance score amounted to 0.376 .

Hypothesis test.

To test the impact of teacher perceptions on the leadership of the school principal, work motivation on teacher performance is carried out using table XI below.

Tabel XI ; Data description on double regretion $\mathrm{X}_{1}, \mathrm{X}_{2}$ and $\mathrm{Y}$

\begin{tabular}{|c|c|c|c|c|c|c|}
\hline \multicolumn{7}{|c|}{ ANOVA $^{a}$} \\
\hline \multicolumn{2}{|c|}{ Model } & Sum of Squares & $\mathrm{df}$ & Mean Square & $\mathrm{F}$ & Sig. \\
\hline \multirow{3}{*}{1} & Regression & 1671.427 & 2 & 835.713 & 12.856 & $.000^{\mathrm{b}}$ \\
\hline & Residual & 3705.423 & 57 & 65.007 & & \\
\hline & Total & 5376.850 & 59 & & & \\
\hline
\end{tabular}

a. Dependent Variable: Teacher preception

b. Predictors: (Constant), Teacher motivation, preception to principal leadership

H_0: $\beta \_y 1=\beta \_y 2=0$, teacher performance together is not influenced by the teacher's perception of the principal's leadership and work motivation.

H_1: $\beta \_y 1 \neq \beta \_y 2 \neq 0$, teacher performance is jointly influenced by the teacher's perception of the principal's leadership and work motivation.

Based on table XI presented above it can be stated that the value of Sig. $0,000<0,05$ and Fcount $=12,856>$ Ftable $=3,19$, this proves that there is a significant influence of teacher perceptions on school leadership and work motivation on teacher performance.

\section{CONCLUSION}

This study states that the value of Sig. $0,000<0,05$ and Fcount $=12,856>$ Ftable $=3,19$, this proves that there is a significant influence of teacher perceptions on school leadership and work motivation on teacher performance.

\section{References}

Abdullah,S.I. ( 2016 ). Aplikasi komputer dalam penyusunan karya ilmiah. Jakarta: Pustaka Mandiri.

Adair, John,(2004). Menjadi pemimpin efektif.Jakarta: PT. Gramedia

Arikunto, Suharsimi,(2006).Prosedur penelitian suatu pendekatan praktis. Jakarta : Rineka Cipta

Azwar, Saifuddin,(2003). Tes Prestasi : Fungsi dan pengembangan pengukuran prestasi belajar. Jakarta : Pustaka 
Pelajar

Brojonagoro,(2002). Norma-norma pendidikan dan tingkat pengembangan anak. Bandung : Rineka Cipta

Davidchoff, LL, (1998). Psikologi suatu pengantar. jilid 1, edisi Bahasa Indonesia oleh Mari Jumiati, Jakarta, Erlangga

Djamarih, Syaiful Bahri,(2005). Strategi belajar mengajar, Jakarta ,Reneka cipta

Ghozali, Imam,(2001). Aplikasi analisis multivariate dengan program SPSS, Semarang, Universitas Diponegoro Hadari H Nawawi,(2005), kepemimpinan mengefektifkan organisasi. Penerbit gajah Mada University Pres, Yogyakarta.

Harna, Mugi, M,.(2003). Profesionalitas kepala sekolah. Pendidikan Network.

Irawan,Prasetya,(2003). Teori belajar, motivasi dan keterampilan mengajar.jakarta,Depdiknas. Kartono,( 2002). Kepemimpinan pendidikan. Jakarta: Prehallindo.

Kartono,( 2002). Kepemimpinan pendidikan. Jakarta: Prehallindo.

Malayu Hasibuan,(2000), Manajemen sumber daya manusia, Jakarta: Bumi Aksara

Mulyasa, E, (2003), Manajemen kepala sekolah profesional dalam penyusunan MBS. Bandung,: PT. Remaja Rosdakarya.

Mulyasa, E. (2002). Kurikulum berbasis kompetensi: konsep,karakteristik dan implementasi, Bandung: PT. Remaja Rosdakarya.

Nawawi, (2003), kepemimpinan yang efektif, Yogyakarta: Gajahmada University press.

Safari, 2005. Tehnik Analisis Butir Soal Instrumen Test dan Non Test. Jakarta, Depdiknas.

Sagala, H. Syaiful, (2014). Manajemen strategik dalam peningkatan mutu pendidikan. Bandung, Alvabeta.

Sudjana,(2005), Metode statistik, Bandung, Tarsito.

Wahyudi,(2010). Kepemimpinan kepala sekolah dalam organisasi pembelajaran. Bandung, Alvabeta,H.123

Yamin, Martinis dan Maisah,(2011). Standarisasi kinerja guru. Jakarta: gaung Persada. 